\title{
A biphasic oxidation of alcohols to aldehydes and ketones using a simplified packed-bed microreactor
}

\author{
Andrew Bogdan ${ }^{1}$ and D. Tyler McQuade ${ }^{*}, 2$
}

\author{
Full Research Paper \\ Address: \\ ${ }^{1}$ Department of Chemistry and Chemical Biology, Cornell University, \\ Ithaca, NY, 14853 USA and ${ }^{2}$ Department of Chemistry and \\ Biochemistry, Florida State University, Tallahassee, FL 32306, USA. \\ Fax (850) 644-8281 \\ Email: \\ D. Tyler McQuade - mcquade@chem.fsu.edu \\ * Corresponding author \\ Keywords: \\ alcohol oxidation; flow chemistry; heterogeneous catalysis; \\ microreactors; TEMPO
}

Open Access

Beilstein Journal of Organic Chemistry 2009, 5, No. 17.

doi:10.3762/bjoc.5.17

Received: 23 December 2008

Accepted: 24 March 2009

Published: 29 April 2009

Guest Editor: A. Kirschning

(C) 2009 Bogdan and McQuade; licensee Beilstein-Institut. License and terms: see end of document.

\begin{abstract}
We demonstrate the preparation and characterization of a simplified packed-bed microreactor using an immobilized TEMPO catalyst shown to oxidize primary and secondary alcohols via the biphasic Anelli-Montanari protocol. Oxidations occurred in high yields with great stability over time. We observed that plugs of aqueous oxidant and organic alcohol entered the reactor as plugs but merged into an emulsion on the packed-bed. The emulsion coalesced into larger plugs upon exiting the reactor, leaving the organic product separate from the aqueous by-products. Furthermore, the microreactor oxidized a wide range of alcohols and remained active in excess of 100 trials without showing any loss of catalytic activity.
\end{abstract}

\section{Introduction}

Microreactors have gained attention because they can help run chemical transformations more efficiently, more selectively, and with a higher degree of safety [1-12]. Alcohol oxidations are well suited for microreactors due to high by-product formation, catalyst contamination and safety concerns often associated with scale-up in batch reactors [13]. Recent developments in microreactor technology and solid-supported catalysis have aimed to solve these issues. Numerous flow oxidations have been presented in the literature [13-16], however many rely on stoichiometric reagents $[17,18]$, suffer from catalyst deactivation $[19,20]$, or rely on soluble catalysts [21], all of which limit their potential as continuous flow processes. Realizing this, we developed a catalytic packed-bed microreactor that could be used for the continuous flow oxidation of alcohols to aldehydes or ketones.

Oxidations that do not require transition metal catalysts are particularly appealing since there is neither leaching nor the need for catalyst regeneration [22]. Nitroxyl radicals, such as 2,2,6,6-tetramethylpiperidine-1-oxyl (TEMPO), immobilized on silicates [23-32], fluorous supports [33], soluble and insoluble polymers [22,34-36], magnetic nanoparticles [37], and ionic liquids [38] have been extensively studied and are useful because the oxidation conditions are mild, selective, and the 


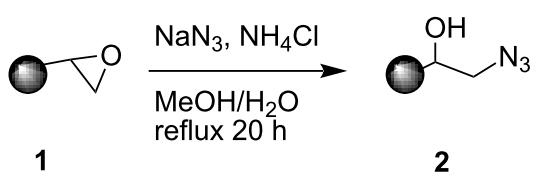

Scheme 1: Preparation of azide-modified AO resin 2

catalysts do not require regeneration. TEMPO, however, is expensive and difficult to remove from reaction mixtures. For these reasons, TEMPO immobilization is an important goal because it enables facile removal and recycling.

We recently reported the development of an effective solid support for use in packed-bed microreactors [39], AMBERZYME ${ }^{\circledR}$ Oxirane (AO, 1), a commercially available resin with pendant epoxide functionalities designed for enzyme immobilization. AO is readily functionalized with a range of catalysts and works well as packing material for flow chemistry [39]. In this report, we demonstrate the immobilization of TEMPO and its use in a flow system using the AnelliMontanari protocol for the oxidation of primary and secondary alcohols $[30,40]$. Our simplified reactor is advantageous because the reactions not only run continuously, but since the microreactor is made of cheap, disposable fluoroelastomeric tubing, wall oxidation that is commonplace with metal microchannels is not observed [21]. The narrow dimensions of the microreactor also allow excellent heat transfer, increasing the safety of large-scale oxidations. Furthermore, it was determined that the use of a packed-bed microreactor facilitates efficient mixing of a biphasic system without destroying the solid support, a common problem with stirred systems [4].

\section{Results and Discussion}

Previously we reported that catalysts functionalized with an acetylene moiety can be tethered to AO using a Huisgen cycloaddition [39]. Azide-functionalized $\mathrm{AO}$ resin $\left(\mathrm{AO}-\mathrm{N}_{3}, 2\right)$ was prepared by treating AO with sodium azide (Scheme 1) [41]. The coupling of 4-hydroxy-TEMPO 3 with propargyl bromide (4) using sodium hydride yielded the acetylene-modified TEMPO species 5 [33,34,37]. TEMPO derivative $\mathbf{5}$ was then covalently bound to AO-N 3 using copper(I) iodide [42-45], yielding the TEMPO-functionalized resin (AO-TEMPO, 6 , Scheme 2, $0.46 \mathrm{mmol} \mathrm{TEMPO} / \mathrm{g}$ resin).

Using a simplified procedure developed by ourselves and others [39,46-49], flow reactions were performed by packing fluoroelastomeric tubing $(60 \mathrm{~cm}, 1.6 \mathrm{~mm}$ i.d.) with the
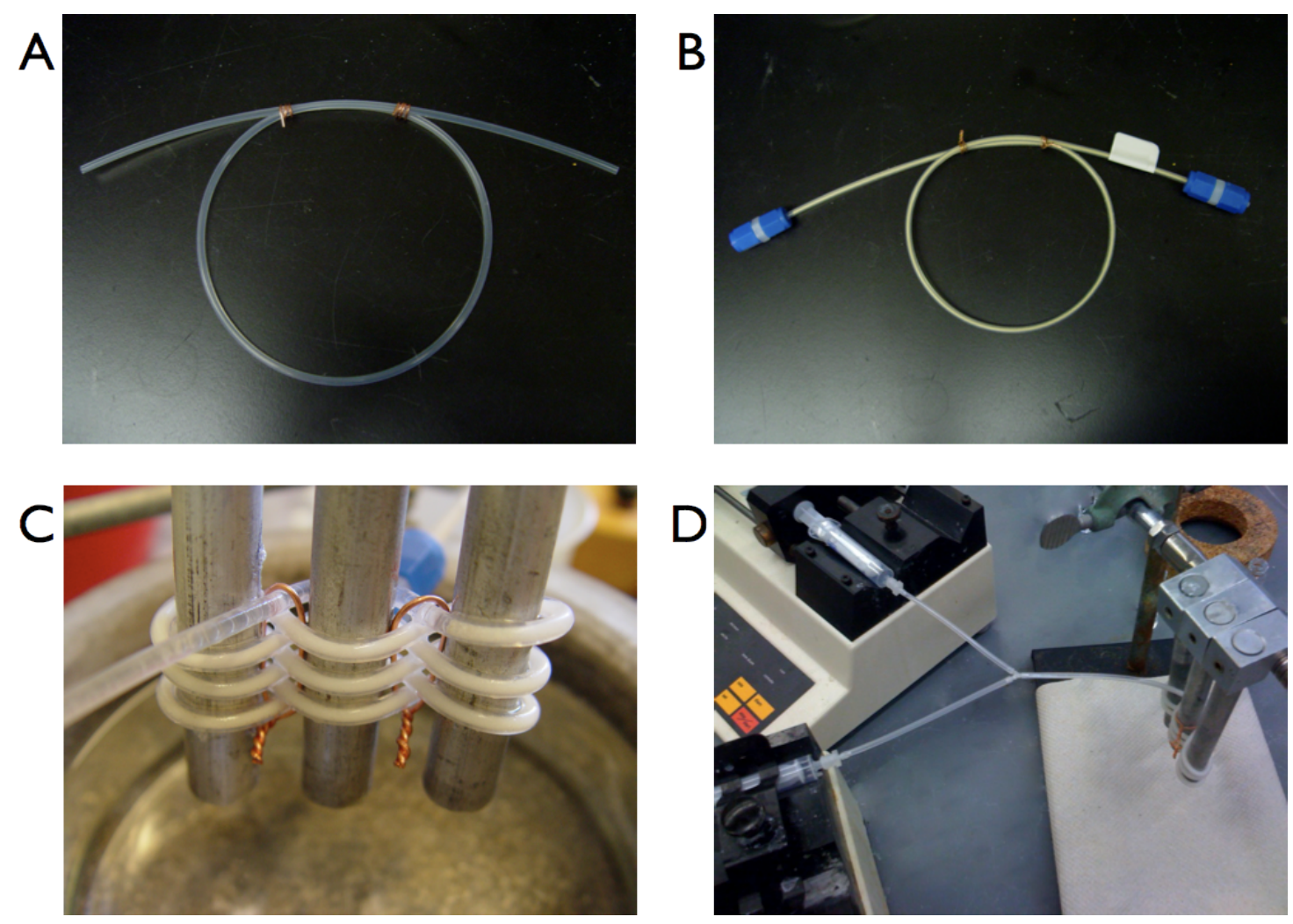

Figure 1: The simplified microreactor setup. Empty tubing $(A)$ is packed with functionalized $A O$ resin and attached to caps (B). The packed bed is woven between metal bars (C) and connected to syringe pumps (D). 


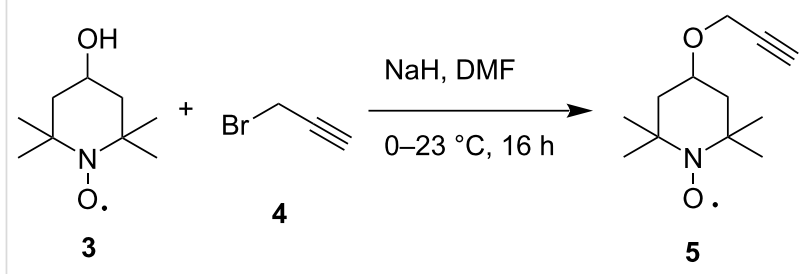

3

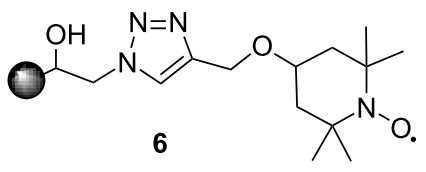

Scheme 2: Preparation of AO-TEMPO 6

AO-TEMPO resin. The tubing was subsequently woven between metal bars, to improve mixing and to enable facile microreactor cooling (Figure 1). A Y-junction placed at the inlet of the microreactor allowed the immiscible bleach (adjusted to pH 9.1 using $\mathrm{NaHCO}_{3}$ ) and organic alcohol solutions to form plugs before reaching the packed bed (Figure 2A). When passing through the AO-TEMPO catalyst bed, the plugs emulsified, as indicated by visual inspection and by the plug coalescence at the microchannel outlet (Figure 2B). The effective mixing was later supported by the high yields and conversions that were achieved for this biphasic reaction.

Preliminary reactions were performed using benzyl alcohol as the test substrate in order to establish the optimal flow conditions (Scheme 3). A solution of benzyl alcohol in $\mathrm{CH}_{2} \mathrm{Cl}_{2}$ $(0.2 \mathrm{M})$, an aqueous $\mathrm{NaOCl}$ solution $(0.25 \mathrm{M}$, adjusted to pH 9.1 using $\mathrm{NaHCO}_{3}$ ), and an aqueous $\mathrm{KBr}$ solution $(0.5 \mathrm{M})$ were prepared. The organic phase was loaded into one syringe and a mixture of $\mathrm{NaOCl}$ and $\mathrm{KBr}(30 \mu \mathrm{L} \mathrm{KBr}$ solution per $\mathrm{mL}$ $\mathrm{NaOCl}$ solution) was added to another. The syringes were placed on separate syringe pumps and the flow rates were regulated such that 1.0 equiv alcohol $\mathrm{min}^{-1}, 1.5$ equiv $\mathrm{NaOCl}$ $\min ^{-1}$, and 0.10 equiv $\mathrm{KBr} \min ^{-1}$ were delivered to the packed bed. Various flow rates were examined to determine the optimal flow conditions for the oxidation. For data relating flow rate to residence time, see Supporting Information File 1. During our optimization studies, it was shown that a total flow rate of $100 \mu \mathrm{L} \mathrm{min}^{-1}$ (aqueous flow rate $56 \mu \mathrm{L} \mathrm{min}^{-1}$ and organic flow

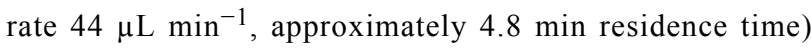
afforded quantitative conversion of benzyl alcohol to benzaldehyde, indicating that efficient mixing was occurring in the

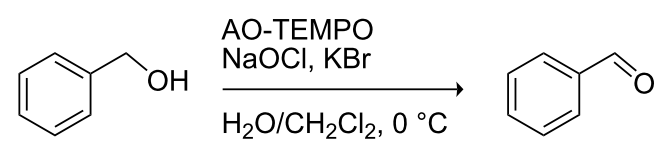

Scheme 3: The AO-TEMPO-catalyzed oxidation of benzyl alcohol.

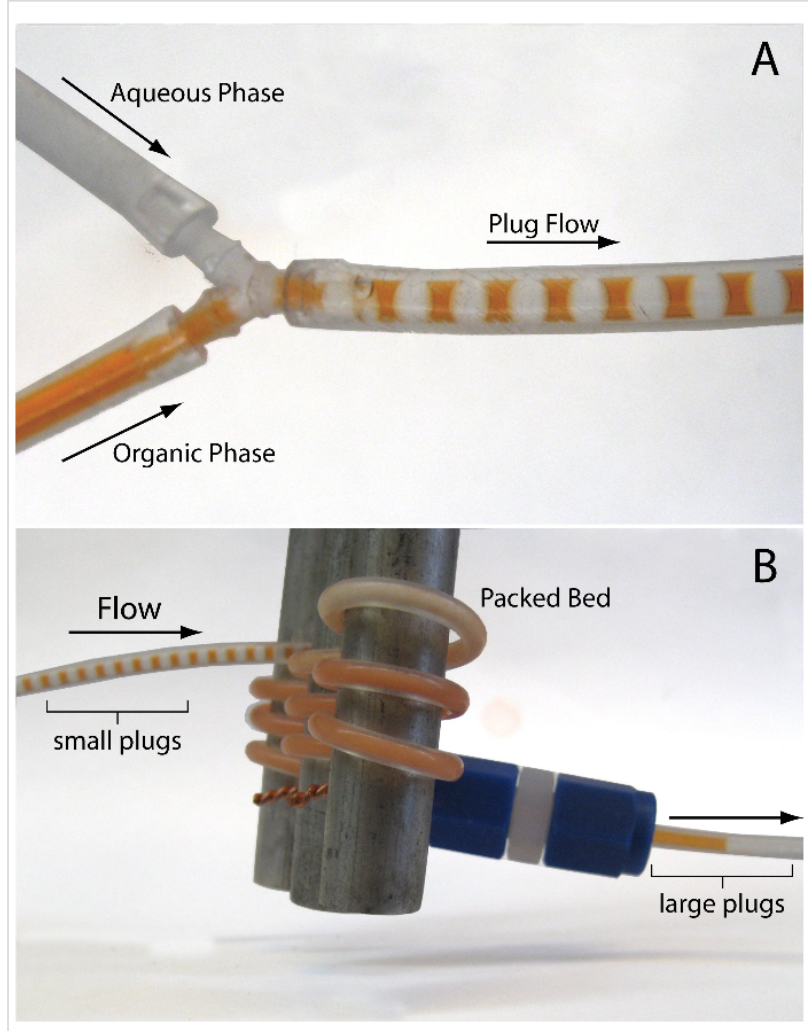

Figure 2: The organic (colored solution) and aqueous phases (colorless solution) forming plugs at the $\mathrm{Y}$-junction (A). The phases mix upon reaching the packed bed, leading to a coalescence of drops at the outlet of the microchannel (B).

column at this flow rate. Faster flow rates $(200$ or $400 \mu \mathrm{L}$ $\min ^{-1}$ ) could also be used to obtain higher outputs of benzaldehyde, however these reaction conditions did not provide complete conversion of starting material.

Using these optimized flow conditions for the benzyl alcohol oxidation, a number of different substrates were examined to test the generality of the AO-TEMPO packed-bed microreactor. High conversions were achieved when using both aromatic and aliphatic alcohols (Table 1, Entries 1-6). Secondary alcohols, which are known to be oxidized at a slower rate than primary alcohols, could effectively be oxidized to ketones by increasing the equivalents of $\mathrm{NaOCl}$ with respect to the alcohol concentration (Table 1, Entries 7-9). Primary alcohols were shown to be oxidized selectively over secondary alcohols (Table 1, Entry 10). Interestingly, it was also demonstrated that ethyl acetate was almost as effective a solvent as methylene chloride, opening the possibility of making this process "green" (Table 1, Entry 11). While reactions range from modest to high yields, systems that do not perform as efficiently could readily be optimized to afford higher conversions and yields. For the purposes of this paper however, we were solely testing the generality of the method and, therefore, did not optimize every 
Table 1: Oxidation of alcohols using AO-TEMPO packed-bed microreactor.

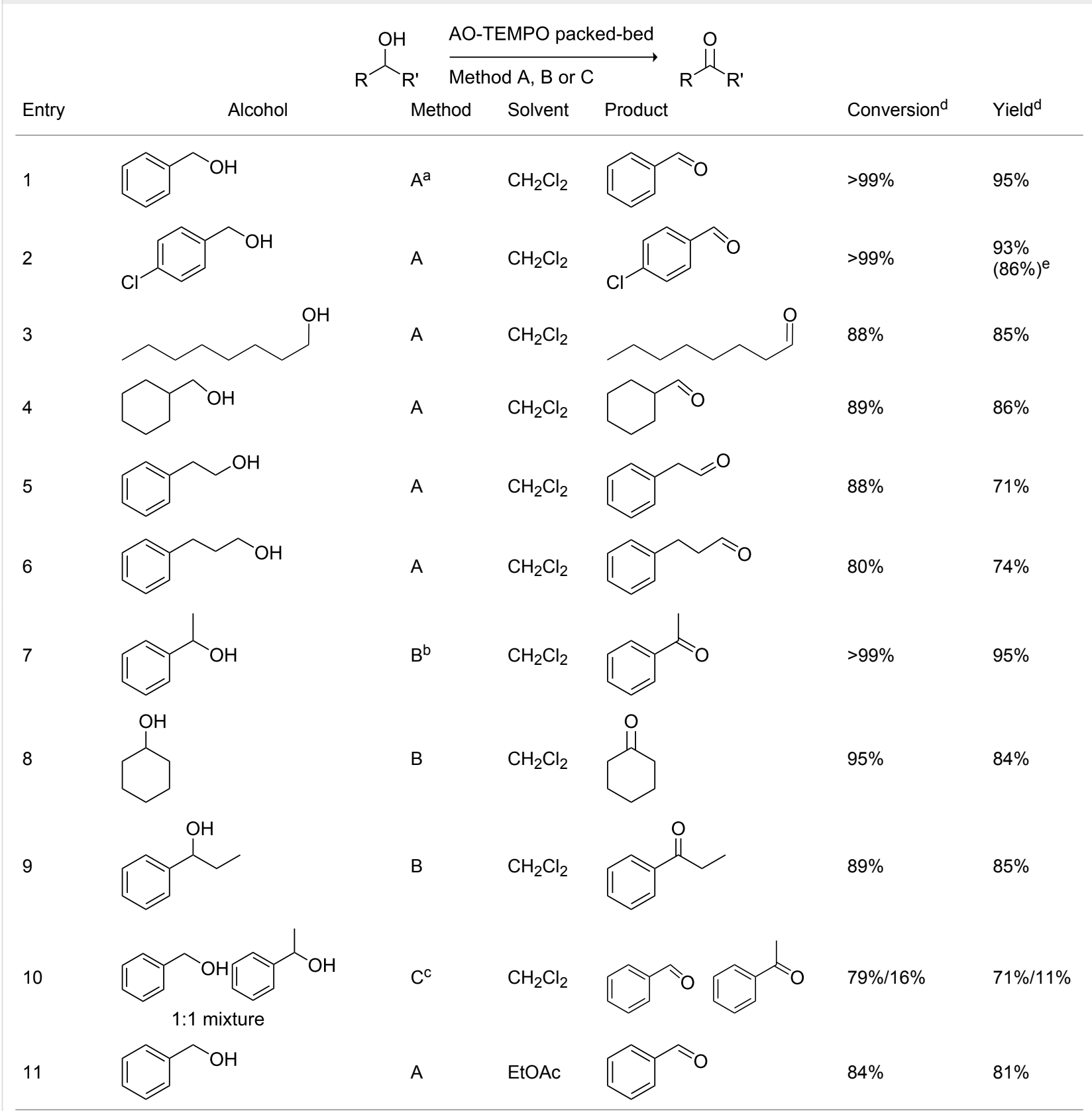

aMethod A: Organic Phase - Alcohol $(0.2 \mathrm{M})$ in $\mathrm{CH}_{2} \mathrm{Cl}_{2}$ or EtOAc set to $44 \mu \mathrm{L} \mathrm{min}^{-1}\left(8.8 \mu \mathrm{mol}\right.$ alcohol min ${ }^{-1}, 1.0$ equiv min $\left.{ }^{-1}\right)$. Aqueous Phase Aqueous $\mathrm{NaOCl}(0.25 \mathrm{M})$, adjusted to $\mathrm{pH} 9.1$ with $\mathrm{NaHCO}_{3}$, mixed with aqueous $\mathrm{KBr}\left(0.5 \mathrm{M}, 30 \mu \mathrm{L}\right.$ per mL NaOCl) set to $56 \mu \mathrm{L}$ min ${ }^{-1}(1.5$ equiv $\mathrm{NaOCl}$ $\mathrm{min}^{-1}, 0.10$ equiv $\left.\mathrm{KBr} \mathrm{min}^{-1}\right)$. The phases combined at a Y-junction and passed through a $60 \mathrm{~cm}$ channel packed with AO-TEMPO (300 mg,

$0.138 \mathrm{mmol}$ TEMPO) submerged in an ice bath. ${ }^{b}$ Method B: Organic Phase - Alcohol $(0.1 \mathrm{M})$ in $\mathrm{CH}_{2} \mathrm{Cl}_{2}$ set to $44 \mu \mathrm{L} \mathrm{min}^{-1}\left(4.4 \mu \mathrm{mol}\right.$ alcohol min ${ }^{-1}$, 1.0 equiv $\left.\mathrm{min}^{-1}\right)$. Aqueous Phase - Aqueous $\mathrm{NaOCl}(0.25 \mathrm{M})$, adjusted to $\mathrm{pH} 9.1$ with $\mathrm{NaHCO}_{3}$, mixed with aqueous $\mathrm{KBr}(0.5 \mathrm{M}, 30 \mu \mathrm{L}$ per mL $\mathrm{NaOCl})$ set to $56 \mu \mathrm{L} \mathrm{min}^{-1}$ ( 3.0 equiv $\mathrm{NaOCl} \mathrm{min}{ }^{-1}, 0.20$ equiv $\mathrm{KBr} \mathrm{min}{ }^{-1}$ ). The phases combined at a $\mathrm{Y}$-junction and passed through a $60 \mathrm{~cm}$ channel packed with AO-TEMPO (300 mg, $0.138 \mathrm{mmol}$ TEMPO) submerged in an ice bath. ${ }^{\mathrm{C}}$ Method C: Organic Phase - Benzyl alcohol (0.2 M) and 1-phenylethanol $(0.2 \mathrm{M})$ in $\mathrm{CH}_{2} \mathrm{Cl}_{2}$ set to $44 \mu \mathrm{L} \mathrm{min} \mathrm{m}^{-1}\left(8.8 \mu \mathrm{mol}\right.$ alcohol $\mathrm{min}^{-1}, 1.0$ equiv $\left.\mathrm{min}^{-1}\right)$. Aqueous Phase - Aqueous $\mathrm{NaOCl}(0.20 \mathrm{M})$, adjusted to $\mathrm{pH} 9.1 \mathrm{with}$ $\mathrm{NaHCO}_{3}$, mixed with aqueous $\mathrm{KBr}(0.5 \mathrm{M}, 30 \mu \mathrm{L}$ per $\mathrm{mL} \mathrm{NaOCl})$ set to $56 \mu \mathrm{L} \mathrm{min}^{-1}\left(1.25\right.$ equiv NaOCl min ${ }^{-1}, 0.10$ equiv KBr min $\left.{ }^{-1}\right)$. The phases combined at a $Y$-junction and passed through a $60 \mathrm{~cm}$ channel packed with AO-TEMPO (300 mg, $0.138 \mathrm{mmol}$ TEMPO) submerged in an ice bath. ${ }^{\mathrm{d}}$ Conversions and yields determined by GC using cyclooctane as an internal standard. eNumber in parentheses corresponds to isolated yield. 
substrate. Similar to our previous packed-bed systems, these AO-TEMPO microchannels showed a high degree of recyclability, in some cases being used in excess of 100 trials without any apparent loss of catalytic activity. Channels also maintained a high activity after three months of not being used.

To test the long-term activity of the AO-TEMPO packed beds, the oxidation of 4-chlorobenzyl alcohol to 4-chlorobenzaldehyde was run continuously and sampled periodically to monitor its activity. As seen in Figure 3, the activity of the catalyst bed remained high even after hours of use. Furthermore, the workup of this simplified oxidation scale-up comprised only of phase separation followed by concentration, yielding a white crystalline solid with greater than $95 \%$ purity by ${ }^{1} \mathrm{H}$ NMR.

\section{Conclusion}

We have demonstrated that using supported TEMPO is an efficient method to oxidize alcohols using a simplified packed-bed microreactor. A biphasic mixture was thoroughly mixed by passing the immiscible liquids through the catalytic packed-bed, leading to no disruptions or degradation of the packing material. Thus, the AO-TEMPO resins are recyclable, showing no loss of catalytic activity and a substrate scope that encompasses many primary and secondary alcohols. The devices presented are predicted to be readily scaled-up to achieve the desired output of a reaction and is of higher throughput than other reported packed-bed microreactors.

\section{Experimental}

\section{General}

Solvents were purified by standard procedures. All other reagents were used as received, unless otherwise noted. Sodium hypochlorite solution (reagent grade, available chlorine 10-15\%) was purchased from Aldrich and titrated before use. ${ }^{1} \mathrm{H}$ NMR and ${ }^{13} \mathrm{C}$ NMR spectra were recorded in $\mathrm{CDCl}_{3}$ on Varian Mercury $300 \mathrm{MHz}$ operating at $300.070 \mathrm{MHz}$ and $75.452 \mathrm{MHz}$, respectively, using the residual solvent peak as reference. ATR-IR was performed on a Nicolet Avatar DTGS 370 infrared spectrometer with Avatar OMNI sampler and OMNIC software. Elemental analysis was performed by Robertson Microlit Laboratories, Inc., in Madison, New Jersey. Gas chromatographic (GC) analyses were performed using an Agilent 7890A GC equipped with an Agilent 7683B autosampler, a flame ionization detector (FID), and a J\&W Scientific $19091 \mathrm{~J}-413$ column (length $=30 \mathrm{~m}$, inner diameter $=$ $320 \mu \mathrm{m}$, and film thickness $=250 \mu \mathrm{m})$. The temperature program for $\mathrm{GC}$ analysis held the temperature constant at $80{ }^{\circ} \mathrm{C}$ for $1 \mathrm{~min}$, heated samples from 80 to $200{ }^{\circ} \mathrm{C}$ at $20{ }^{\circ} \mathrm{C} / \mathrm{min}$ and held at $200{ }^{\circ} \mathrm{C}$ for $1 \mathrm{~min}$. Inlet and detector temperatures were set constant at 220 and $250{ }^{\circ} \mathrm{C}$, respectively. Cyclooctane was used as an internal standard to calculate reaction conversion and

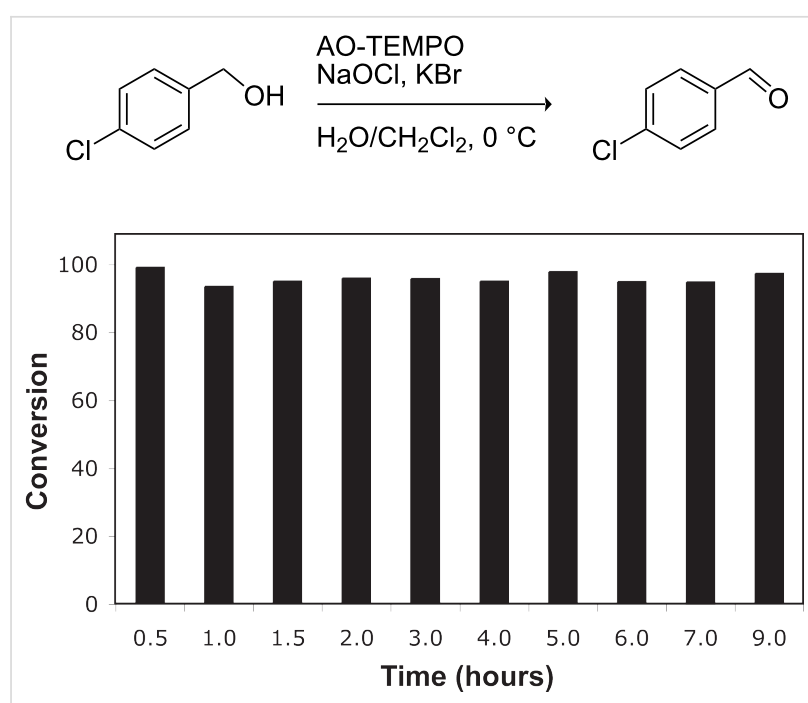

Figure 3: The long-term activity of AO-TEMPO packed beds in the oxidation of 4-chlorobenzyl alcohol. A solution of 4-chlorobenzyl alcohol $\left(0.2 \mathrm{M}\right.$ in $\left.\mathrm{CH}_{2} \mathrm{Cl}_{2}\right)$ set to $44 \mu \mathrm{L} \min ^{-1}\left(8.8 \mu \mathrm{mol} \mathrm{min}^{-1}\right.$,

1.0 equiv $\left.\mathrm{min}^{-1}\right)$ and an aqueous solution consisting of $\mathrm{NaOCl}(0.25$ $\mathrm{M})$, adjusted to $\mathrm{pH} 9.1$ with $\mathrm{NaHCO}_{3}$, and $\mathrm{KBr}(0.5 \mathrm{M}, 30 \mu \mathrm{L}$ per $\mathrm{mL}$ $\mathrm{NaOCl}$ ) set to $56 \mu \mathrm{L}$ min $^{-1}$ (1.5 equiv $\mathrm{NaOCl}$ min $^{-1}, 0.10$ equiv $\mathrm{KBr}$ $\mathrm{min}^{-1}$ ) were passed through the AO-TEMPO packed bed for $9 \mathrm{~h}$. Fractions were collected and analyzed by GC using an internal standard.

yield. Gas chromatography-mass spectrometry (GC/MS) analyses were performed using a Hewlett Packard HP 6890 Series Gas Chromatograph, a Hewlett Packard HP 5973 Mass Spectrometer Detector (MSD), and a J\&W Scientific DB*-5 Column (length $=30 \mathrm{~m}$, inner diameter $=0.325 \mathrm{~mm}$, film thickness $=1.0 \mu \mathrm{m}$, catalog number 123-5033). The temperature program for the analyses held the temperature constant at $50{ }^{\circ} \mathrm{C}$ for $3 \mathrm{~min}$, heated samples from 50 to $80^{\circ} \mathrm{C}$ at $30^{\circ} \mathrm{C} / \mathrm{min}$, holding at $80^{\circ} \mathrm{C}$ for $2 \mathrm{~min}$, then heating samples from 80 to $200{ }^{\circ} \mathrm{C}$ at $17^{\circ} \mathrm{C} / \mathrm{min}$, and holding at $200{ }^{\circ} \mathrm{C}$ for $1.94 \mathrm{~min}$. The MSD temperature was held at $300{ }^{\circ} \mathrm{C}$ for $15 \mathrm{~min}$.

\section{Azide modified AMBERZYME ${ }^{\circledR}$ Oxirane $\left(\mathrm{AO}-\mathrm{N}_{3}, 2\right)$}

Sodium azide (5.26 g, $81 \mathrm{mmol}, 8.1$ equiv) and ammonium chloride (2.27 g, $42.4 \mathrm{mmol}, 4.2$ equiv) were dissolved in $500 \mathrm{~mL} 90: 10 \mathrm{v} / \mathrm{v}$ water in methanol. AMBERZYME ${ }^{\circledR}$ Oxirane (10.0 g, $1.0 \mathrm{mmol}$ epoxide/g resin, $10.0 \mathrm{mmol}, 1.0$ equiv) was suspended in the azide solution and the reaction mixture refluxed overnight with gentle stirring. The resin was filtered using a Buchner funnel, washed with deionized $\mathrm{H}_{2} \mathrm{O}(2 \times$ $50 \mathrm{~mL}), \mathrm{MeOH}(2 \times 50 \mathrm{~mL}), \mathrm{Et}_{2} \mathrm{O}(1 \times 25 \mathrm{~mL})$, and dried under vacuum. Elemental analysis afforded a loading of $1.0 \mathrm{mmol}$ $\mathrm{N}_{3} / \mathrm{g}$ resin.

\section{Propargyl ether TEMPO 5}

Sodium hydride (150 mg, $6.3 \mathrm{mmol}, 1.1$ equiv) was added to DMF (10 mL) and stirred at RT. 4-hydroxy-TEMPO (1.02 g, 
$5.9 \mathrm{mmol}, 1.0$ equiv) in DMF $(10 \mathrm{~mL})$ was added drop wise to the sodium hydride suspension at $0{ }^{\circ} \mathrm{C}$ and stirred until gas evolution ceased. Propargyl bromide ( $80 \%$ in toluene, $800 \mu \mathrm{L}$, $7.4 \mathrm{mmol}, 1.3$ equiv) in DMF $(10 \mathrm{~mL})$ was added at $0{ }^{\circ} \mathrm{C}$ and the reaction was allowed to warm up to RT and stirred overnight. The reaction was quenched with water and the aqueous phase was extracted with ethyl acetate $(3 \times 50 \mathrm{~mL})$ and the combined organic extracts dried over $\mathrm{MgSO}_{4}$, concentrated and dried under vacuum. The product was purified using column chromatography (silica gel, 1:1 $\rightarrow 1: 2$ hexanes/ethyl acetate, $R_{f}=0.40$ ) to yield a dark orange solid ( $841 \mathrm{mg}, 68 \%$ ). $\delta_{\mathrm{C}}\left(75 \mathrm{MHz}, \mathrm{CDCl}_{3}\right): 20.619,32.199,44.530,55.298,59.198$, 69.905, 74.238; MS $m / z 210\left(\mathrm{M}^{+}\right)$. To obtain NMR spectra, a few drops of phenylhydrazine were added to the NMR tube to reduce the product to the corresponding hydroxylamine.

\section{AO-TEMPO 6}

5 (450 mg, $2.14 \mathrm{mmol}, 1.3$ equiv) and $\mathrm{CuI}$ (40 mg, $0.2 \mathrm{mmol}$, 0.13 equiv) were dissolved in anhydrous THF $(20 \mathrm{~mL}) .2$ ( $1.64 \mathrm{~g}, 1.0 \mathrm{mmol} \mathrm{N}_{3} / \mathrm{g}$ resin, $1.64 \mathrm{mmol}, 1.0$ equiv) was added to the solution and placed under a $\mathrm{N}_{2}$ atmosphere. The suspension was shaken for $3 \mathrm{~d}$. The resin was washed with THF $(2 \times$ $10 \mathrm{~mL}), \mathrm{MeOH}(1 \times 10 \mathrm{~mL}), 1 \mathrm{M} \mathrm{HCl}(2 \times 10 \mathrm{~mL})$, deionized $\mathrm{H}_{2} \mathrm{O}(1 \times 10 \mathrm{~mL})$, sat. $\mathrm{NaHCO}_{3}(2 \times 10 \mathrm{~mL})$, deionized $\mathrm{H}_{2} \mathrm{O}(1$ $\times 10 \mathrm{~mL}), \mathrm{MeOH}(1 \times 10 \mathrm{~mL})$ and $\mathrm{CH}_{2} \mathrm{Cl}_{2}(1 \times 10 \mathrm{~mL})$, and dried under vacuum to yield the white AO-TEMPO resin (1.81 g, $0.46 \mathrm{mmol} \mathrm{TEMPO} / \mathrm{g}$ resin). The loading was calculated by mass difference.

\section{Supporting Information}

\section{Supporting Information File 1 \\ Experimental methods and spectral data \\ [http://beilstein-journals.org/bjoc/content/supplementary/ \\ 1860-5397-5-17-S1.pdf]}

\section{Acknowledgments}

We thank NSF SGER, ARO (Grant No. W911NF-06-1-0315), NSF (CHE-0809261), and Florida State University for financial support.

\section{References}

1. Mason, B. P.; Price, K. E.; Steinbacher, J. L.; Bogdan, A. R.; McQuade, D. T. Chem. Rev. 2007, 107, 2300-2318. doi:10.1021/cr050944c

2. Hessel, V.; Löb, P.; Löwe, H. Curr. Org. Chem. 2005, 9, 765-787. doi:10.2174/1385272053764953

3. Hessel, V.; Löwe, H. Chem. Eng. Technol. 2005, 28, 267-284. doi:10.1002/ceat.200407167

4. Hodge, P. Curr. Opin. Chem. Biol. 2003, 7, 362-373. doi:10.1016/S1367-5931(03)00052-8
5. Jas, G.; Kirschning, A. Chem.-Eur. J. 2003, 9, 5708-5723. doi:10.1002/chem.200305212

6. Kirschning, A.; Monenschein, H.; Wittenberg, R. Angew. Chem., Int. Ed. 2001, 40, 650-679. doi:10.1002/1521-3773(20010216)40:4<650::AID-ANIE6500>3.0.CO;2 $-\mathrm{C}$

7. Pennemann, H.; Watts, P.; Haswell, S. J.; Hessel, V.; Löwe, H. Org. Process Res. Dev. 2004, 8, 422-439. doi:10.1021/op0341770

8. Haswell, S. J.; Watts, P. Green Chem. 2003, 5, 240-249. doi:10.1039/b210539j

9. Wirth, T., Ed. Microreactors in Organic Synthesis and Catalysis; Wiley-VCH: Weinheim, 2008.

10. Yoshida, J.-i.; Nagaki, A.; Yamada, T. Chem.-Eur. J. 2008, 14, 7450-7459. doi:10.1002/chem.200800582

11. Watts, P.; Wiles, C. Org. Biomol. Chem. 2007, 5, 727-732. doi:10.1039/b617327f

12. Ahmed-Omer, B.; Brandt, J. C.; Wirth, T. Org. Biomol. Chem. 2007, 5, 733-740. doi:10.1039/b615072a

13. Kawaguchi, T.; Miyata, H.; Ataka, K.; Mae, K.; Yoshida, J.-i. Angew. Chem., Int. Ed. 2005, 44, 2413-2416. doi:10.1002/anie.200462466

14. Kobayashi, S.; Miyamura, H.; Akiyama, R.; Ishida, T. J. Am. Chem. Soc. 2005, 127, 9251-9254. doi:10.1021/ja051246c

15. Tanaka, H.; Chou, J.; Mine, M.; Kuroboshi, M. Bull. Chem. Soc. Jpn. 2004, 77, 1745-1755. doi:10.1246/bcsj.77.1745

16. Kirschning, A.; Altwicker, C.; Dräger, G.; Harders, J.; Hoffmann, N.; Hoffman, U.; Schönfeld, H.; Solodenko, W.; Kunz, U. Angew. Chem., Int. Ed. 2001, 40, 3995-3998. doi:10.1002/1521-3773(20011105)40:21<3995::AID-ANIE3995>3.0.CO ;2-V

17. Baxendale, I. R.; Deeley, J.; Griffiths-Jones, C. M.; Ley, S. V.; Saaby, S.; Tranmer, G. K. Chem. Commun. 2006, 2566-2568. doi:10.1039/b600382f

18. Wiles, C.; Watts, P.; Haswell, S. J. Tetrahedron Lett. 2006, 47, 5261-5264. doi:10.1016/j.tetlet.2006.05.157

19. Cao, E.; Motherwell, W. B.; Gavriilidis, A. Chem. Eng. Technol. 2006, 29, 1372-1375. doi:10.1002/ceat.200600107

20. Kuno, H.; Shibagaki, M.; Takahashi, K.; Matsushita, H. Bull. Chem. Soc. Jpn. 1991, 64, 312-314. doi:10.1246/bcsj.64.312

21. Fritz-Langhals, E. Org. Process Res. Dev. 2005, 9, 577-582. doi:10.1021/op050040t

22. Pozzi, G.; Cavazzini, M.; Quici, S.; Benaglia, M.; Dell'Anna, G. Org. Lett. 2004, 6, 441-443. doi:10.1021/ol036398w

23. Ciriminna, R.; Bolm, C.; Fey, T.; Pagliaro, M. Adv. Synth. Catal. 2002, 344, 159-163. doi:10.1002/1615-4169(200202)344:2<159::AID-ADSC159>3.0.CO;2Q

24. Ciriminna, R.; Pagliaro, M. Adv. Synth. Catal. 2003, 345, 383-388. doi:10.1002/adsc.200390043

25. Ciriminna, R.; Pagliaro, M. Org. Process Res. Dev. 2006, 10, 320-326. doi:10.1021/op050211u

26. Gancitano, P.; Ciriminna, R.; Testa, M. L.; Fidalgo, A.; Ilharco, L. M.; Pagliaro, M. Org. Biomol. Chem. 2005, 3, 2389-2392. doi:10.1039/b505949f

27. Pagliaro, M.; Ciriminna, R.; Man, M. W. C.; Campestrini, S. J. Phys. Chem. B 2006, 110, 1976-1988. doi:10.1021/jp055697v

28. Fidalgo, A.; Ciriminna, R.; Ilharco, L. M.; Pagliaro, M. Chem. Mater. 2005, 17, 6686-6694. doi:10.1021/cm051954x 
29. Testa, M. L.; Ciriminna, R.; Hajji, C.; Garcia, E. Z.; Ciclosi, M.; Arques, J. S.; Pagliaro, M. Adv. Synth. Catal. 2004, 346, 655-660. doi:10.1002/adsc.200303239

30. Bolm, C.; Fey, T. Chem. Commun. 1999, 1795-1796. doi:10.1039/a905683a

31. Brunel, D.; Fajula, F.; Nagy, J. B.; Deroide, B.; Verhoef, M. J.; Veum, L.; Peters, J. A.; van Bekkum, H. Appl. Catal., A 2001, 213, 73-82. doi:10.1016/S0926-860X(00)00886-3

32. Fey, T.; Fischer, H.; Bachmann, S.; Albert, K.; Bolm, C. J. Org. Chem. 2001, 66, 8154-8159. doi:10.1021/jo010535q

33. Gheorghe, A.; Cuevas-Yañez, E.; Horn, J.; Bannwarth, W.; Narsaiah, B.; Reiser, O. Synlett 2006, 2767-2770. doi:10.1055/s-2006-950256

34. Gheorghe, A.; Matsuno, A.; Reiser, O. Adv. Synth. Catal. 2006, 348, 1016-1020. doi:10.1002/adsc.200606043

35. Gilhespy, M.; Lok, M.; Baucherel, X. Chem. Commun. 2005, 1085-1086. doi:10.1039/b415902k

36. Gilhespy, M.; Lok, M.; Baucherel, X. Catal. Today 2006, 117, 114-119. doi:10.1016/j.cattod.2006.05.039

37. Schätz, A.; Grass, R. N.; Stark, W. J.; Reiser, O Chem.-Eur. J. 2008, 14, 8262-8266. doi:10.1002/chem.200801001

38. Wu, X.-E.; Ma, L.; Ding, M.-X.; Gao, L.-X. Synlett 2005, 4, 607-610. doi:10.1055/s-2005-862396

39. Bogdan, A. R.; Mason, B. P.; Sylvester, K. T.; McQuade, D. T. Angew. Chem., Int. Ed. 2007, 46, 1698-1701. doi:10.1002/anie.200603854

40. Anelli, P. L.; Biffi, C.; Montanari, F.; Quici, S. J. Org. Chem. 1987, 52, 2559-2562. doi:10.1021/jo00388a038

41. Chini, M.; Crotti, P.; Macchia, F. Tetrahedron Lett. 1990, 31, 5641-5644 doi:10.1016/S0040-4039(00)97921-8

42. Kolb, H. C.; Finn, M. G.; Sharpless, K. B. Angew. Chem., Int. Ed. 2001, 40, 2004-2021. doi:10.1002/1521-3773(20010601)40:11<2004::AID-ANIE2004>3.0.CO ;2-5

43. Rostovtsev, V. V.; Green, L. G.; Fokin, V. V.; Sharpless, K. B. Angew. Chem., Int. Ed. 2002, 41, 2596-2599. doi:10.1002/1521-3773(20020715)41:14<2596::AID-ANIE2596>3.0.CO ;2-4

44. Wu, P.; Feldman, A. K.; Nugent, A. K.; Hawker, C. J.; Scheel, A.; Voit, B.; Pyun, J.; Fréchet, J. M. J.; Sharpless, K. B.; Fokin, V. V. Angew. Chem., Int. Ed. 2004, 43, 3928-3932. doi:10.1002/anie.200454078

45. Tornøe, C. W.; Christensen, C.; Meldal, M. J. Org. Chem. 2002, 67, 3057-3064. doi:10.1021/jo011148j

46. Poe, S. L.; Cummings, M. A.; Haaf, M. P.; McQuade, D. T. Angew. Chem., Int. Ed. 2006, 45, 1544-1548. doi:10.1002/anie.200503925

47. Quevedo, E.; Steinbacher, J.; McQuade, D. T. J. Am. Chem. Soc. 2005, 127, 10498-10499. doi:10.1021/ja0529945

48. Steinbacher, J. L.; Moy, R. W. Y.; Price, K. E.; Cummings, M. A.; Roychowdhury, C.; Buffy, J. J.; Olbricht, W. L.; Haaf, M.; McQuade, D. T. J. Am. Chem. Soc. 2006, 128, 9442-9447. doi:10.1021/ja0612403

49. Hatakeyama, T.; Chen, D. L. L.; Ismagilov, R. F. J. Am. Chem. Soc. 2006, 128, 2518-2519. doi:10.1021/ja057720w

\section{License and Terms}

This is an Open Access article under the terms of the Creative Commons Attribution License

(http://creativecommons.org/licenses/by/2.0), which permits unrestricted use, distribution, and reproduction in any medium, provided the original work is properly cited.

The license is subject to the Beilstein Journal of Organic Chemistry terms and conditions:

(http://www.beilstein-journals.org/bjoc)

The definitive version of this article is the electronic one which can be found at: doi:10.3762/bjoc. 5.17 